\title{
Occupational change and social polarisation in Ireland: further evidence
}

\author{
PROINNSIAS BREATHNACH \\ Department of Geography and \\ National Institute for Regional and Spatial Analysis (NIRSA) \\ National University of Ireland, Maynooth
}

ABSTRACT: This paper extends to the year 2002 that section of an earlier paper (Breathnach 2002b) which considered whether the pattern of occupational change occurring in Ireland during the period 1991-1996 indicated the operation of processes of social polarisation. The occupational categories contained in the Census of Population were recast in order to create a set of broad groups which facilitated analysis from a social polarisation perspective. This analysis demonstrated strong growth, on the one hand, in the numbers of employers \& managers and professional \& technical workers and, on the other, in certain unskilled occupational groups (personal services and retail sales) - the latter following the allocation to these groups of the bulk of the greatly-expanded number of workers who failed to state their occupation in the 2002 census. Meanwhile, key middle-income groups, including bluecollar industrial, clerical and public service workers experienced contraction in their overall share of employment. These findings provide considerable support for the social polarisation hypothesis, albeit in the context of overall professionalisation of the occupational structure. Female workers have been to the fore in driving these processes of change, in that there has been aboveaverage growth of female employment in those occupational categories at both ends of the occupational spectrum.

KEYWORDS: social polarisation, occupational change, professionalisation, feminisation, Ireland

\section{Introduction}

In an earlier issue of this journal, the present writer reviewed the theoretical argumentation and empirical evidence relating to the notion that a process of social polarisation has been occurring throughout the world's advanced economies 
in recent decades (Breathnach 2002b). A key element of this review was an examination of occupational change in Ireland in the intercensal period 1991-6 in order to identify whether the pattern of change was along lines that would have been predicted by social polarisation theory. The broad, and necessarily tentative, conclusion drawn from this analysis was that tendencies towards polarisation were in evidence, with above-average growth occurring in both high-level and lowlevel (in terms of remuneration and social status) occupational groups (with stronger growth occurring in the higher-level groups), while traditional middleincome groups experienced relative decline. The purpose of the present paper is to both deepen this analysis and to extend the review period to 2002 following the publication of the population census taken in that year. The paper begins with a brief reprise of the theory underlying the social polarisation concept, which is followed by an account of the manner in which the census data on occupations were recast in order to facilitate analysis from a social polarisation viewpoint. The results of this analysis are then presented and discussed.

\section{The social polarisation process}

The operation of a process of social polarisation, it has been suggested, is reflected in the simultaneous growth of both high- and low-income occupations, and the relative (if not absolute) decline of middle-income occupations in the world's advanced economies since the 1970s. This reshaping of occupational configurations, in turn, has been attributed to a series of interrelated economic, political and technological developments associated with the transition from the so-called 'Fordist' form of industrial society which dominated the western world in the period after the Second World War to what Castells (1996) terms the post-Fordist 'informational' society which has been emerging in recent years. ${ }^{1}$

The emergence of informationalism, it is argued, has engendered rapid growth in professional employment in such areas as marketing, management, information technology, financial services and entertainment. The consumer spending of these affluent workers, in turn, has generated corresponding growth in a wide range of businesses in such areas as retailing, restaurants, hotels, bars, real estate, security and personal services. While the growth of these businesses has added further to the expansion of high-income work (in the form of their owners and managers), it has also occasioned strong simultaneous growth in poorly-paid employment in such areas as catering, retailing, cleaning, leisure, personal care, and retailing. Meanwhile, the middle-income groups such as semi-skilled manufacturing workers, clerical workers and public service employees, whose expansion and mass consumption underpinned Fordist mass production, have seen their position eroded by a combination of technological change and public sector cutbacks.

While there is widespread agreement that occupational structures have been changing in the advanced economies in recent decades, the opposite applies to how these changes have been interpreted. Thus, while some, such as Castells 
(1996) and Harrison (1997), have advanced the conventional polarisation thesis, i.e. that there has been growth at both the upper and lower ends of the employment spectrum and decline in the middle, others (e.g. Graham and Marvin 1996) have argued that growth has been concentrated among lower-end occupations while still others (e.g. Belchamber 1996) have argued that employment growth has mainly occurred at the other end of the spectrum, a process which Hamnett (1994) has termed 'professionalisation'. Such differences of view have also emerged in the analysis of occupational change in Ireland in the 1990s, with O'Hearn (2000), for example, advancing the second of these positions and O'Connell (2000) the third.

\section{Methodological considerations in seeking evidence for social polarisation}

Such profoundly variant views may be attributed, to an extent, to the use of unsatisfactory occupational taxonomies in the analysis of employment change. Broad occupational classifications can be very crude, lumping quite different occupations into the same categories. Official classifications may also have failed to keep pace with the growth of new occupations, or with the fact that the type of work performed in certain occupational categories may have changed markedly over time. In the case of Ireland, the Central Statistics Office (CSO) took account of such considerations in employing a greatly revised occupational classification, designed to take account of the emergence of new occupations, in the 1996 and 2002 Censuses of Population. ${ }^{2}$ The returns from the 1991 Census were also reclassified according to the new taxonomy, thereby providing the basis for an analysis of occupational change over the 1991-2002 period.

The new classification system introduced in 1996 is based on the UK Standard Occupational Classification (SOC), with some modifications to reflect Irish labour market conditions, and divides the Irish labour force initially into 227 detailed (three-digit) occupational subcategories. However, while the SOC combines these three-digit subcategories into nine broad one-digit categories (based on skill and remuneration level), this latter classification is not used in the occupational volumes of the 1996 and 2002 censuses (although, oddly, this is the occupational classification used in the 2003 National Employment Survey and the Quarterly National Household Survey - see below - both also published by the CSO). Instead, in the census volumes the three-digit occupational subcategories are grouped into no less than four alternative taxonomies, including a nine-category 'broad' and a 25-category 'intermediate' taxonomy in both of which occupations are classified along traditional sectoral lines similar to the Standard Industrial Classification, and two further taxonomies based on, respectively, 11 'socio-economic' and seven 'social class' categories which are confusingly similar.

According to the explanatory appendix in the occupational volume of the 2002 census (Central Statistics Office 2003: 126-7), the difference between the two latter taxonomies is that the former is deemed to be non-hierarchical while the latter purportedly ranks occupational categories in terms of the skill levels 
involved in each. However, close scrutiny of the occupational groups included in the different 'social class' categories indicates some allocations which are hardly in keeping with this criterion. For example, this taxonomy includes a 'nonmanual' category which combines restaurant and catering managers (strangely, not included in the 'managerial/technical' category), clerical workers, soldiers and police with sales assistants, checkout operators and petrol pump attendants. Its 'skilled manual' category includes, along with traditional craft occupations such as fitters, electricians and carpenters, such occupations as travel and flight assistants, childminders, roundsmen/women and a range of industrial operatives, while its 'semi-skilled' category includes, on the one hand, such groups as farmers, scaffolders and machinists and, on the other, bar staff, waiters/waitresses, carers, street traders, hotel porters and a further range of industrial operatives. This leaves, almost as a residual, a very attenuated 'unskilled' category which amounted to just six per cent of the total labour force in 2002.

It is difficult to comprehend the rationale behind such a classification which combines highly disparate occupational groups involving very different skill levels in the same occupational categories. Thus, this taxonomy is not usable as a basis for tracking social polarisation within the Irish labour force in the 1990s, as it combines in certain categories occupational groupings whose behaviour over time would be expected to be quite divergent according to social polarisation theory. As it happens, the SOC's original nine-category broad occupational taxonomy is, in fact, much more amenable to the analysis of occupational change in terms of social polarisation theory. The categories involved in this taxonomy, and the levels of earnings associated with each as elicited from the 2003 National Employment Survey, are shown in Table 1. Because earnings typically portray a positively skewed distribution pattern, both median and mean hourly earnings are shown, but only the mean weekly earnings are given in the original source. Table 1 portrays a very clear hierarchical structure in terms of the distribution of mean weekly earnings. The managers and administrators category has by far the highest mean weekly earnings. However this is, to a considerable extent, attributable to the longer hours worked, on average, by this group whose mean hourly earnings were, in fact, less than those for professional workers. ${ }^{3}$ The latter category is made up mainly of workers with university degrees; in 2002 its principal subgroups were teachers, engineers and accountants. There is a high degree of commonality between the managers/administrators and professional categories in terms of educational qualifications, and this is reflected in the fact that these two categories have by far the highest mean weekly earnings in Table 1.

Two other occupational categories - associate professional \& technical and craft \& related - are shown in Table 1 to have above-average mean weekly earnings. The members of the associate professional/technical category would for the most part, have undergone a substantial degree of formal training (although not normally to degree level): the leading components of this grouping are nurses, technicians and computer programmers. The craft $\&$ related category consists, for 
Table 1: Employee earnings by occupational group ${ }^{1}, 2003$

\begin{tabular}{lccccr}
\hline Occupational group & $\begin{array}{c}\text { Mean } \\
\text { hourly } \\
\text { earnings } \\
€\end{array}$ & $\begin{array}{c}\text { Median } \\
\text { hourly } \\
\text { earnings } \\
€\end{array}$ & $\begin{array}{c}\text { Mean } \\
\text { weekly } \\
\text { hours } \\
\text { worked }\end{array}$ & $\begin{array}{c}\text { Mean } \\
\text { weekly } \\
\text { earnings } \\
€\end{array}$ & $\begin{array}{c}\text { Numbers } \\
\text { employed } \\
\text { (000) }\end{array}$ \\
\hline Managers \& administrators & 26.17 & 20.92 & 35.4 & 944.35 & 158.6 \\
Professional & 26.31 & 24.05 & 29.8 & 777.55 & 172.5 \\
Associate professional \& technical & 18.37 & 16.09 & 32.1 & 605.85 & 144.0 \\
Craft \& related & 14.58 & 13.25 & 37.2 & 586.29 & 178.2 \\
Plant \& machine operatives & 12.71 & 11.41 & 38.1 & 520.32 & 150.7 \\
Clerical \& secretarial & 14.02 & 12.17 & 32.1 & 462.92 & 208.8 \\
Personal \& protective services & 11.57 & 10.19 & 32.2 & 418.82 & 168.1 \\
Other & 11.70 & 10.14 & 31.4 & 395.17 & 122.7 \\
Sales & 10.83 & 9.11 & 28.0 & 339.31 & 137.0 \\
Total & 16.41 & 13.08 & 33.0 & 566.51 & $1,440.0$ \\
\hline
\end{tabular}

${ }^{1}$ Excluding agriculture, forestry \& fishing

Source: Central Statistics Office (2006)

the most part, of craft workers who traditionally would have served apprenticeships (carpenters, plumbers, mechanics, electricians, etc.) and semi-skilled manufacturing workers (printers, metal workers, machinists, etc.).

As regards those occupational categories in Table 1 with below-average weekly earnings, the plant and machine operatives grouping is made up mainly of manufacturing operatives \& assembly workers and vehicle drivers, while the clerical/ secretarial category (numerically the largest in Table 1) is made up principally of clerks, clerical officers, secretaries and receptionists. Clerical workers comprise a significant portion of the workforce who, despite in most cases being well-educated and in many cases having significant skill levels, are generally in receipt of relatively low remuneration levels. This primarily reflects the fact that this occupational group is predominantly female (77 per cent in the case of Ireland in 2002) - such groups traditionally being undervalued in Irish society (Breathnach 2002a).

The personal \& protective services category listed in Table 1 combines workers with a considerable level of formal training (defence forces, police, fire fighters, prison officers, chefs, hairdressers) with workers with little or no such training (mainly care assistants, nurses' aids, waitresses, bar staff and caretakers). This renders the mean weekly earnings figure for this occupational category rather meaningless, since, for example, the respective figures for the defence forces (€603.22) and especially for the Garda (€937.67) in June 2003 (Central Statistics Office 2007) were well above the overall mean for the category (€418.82) shown in Table 1. Accordingly, the mean weekly earnings for the unskilled members of the grouping must have been well below the overall category mean. This indicates that 
the two groups should be separated in any analysis seeking to track occupational change in terms of the social polarisation hypothesis.

The 'other' category listed in Table 1 consists mainly of unskilled manual workers, especially labourers, cleaners and counterhands. Like the personal/ protective services category, the remaining category in Table 1 - sales - combines very different subgroups in terms of skill and remuneration levels. with over half of the grouping consisting of sales assistants, checkout operators and petrol pump attendants, and most of the remainder comprising auctioneers/valuers and sales representatives whose remuneration profile is, in most cases, likely to be substantially different. Thus, in 2003,47 per cent of those working in the wholesale \& retail trade sector were earning less than $€ 10$ per hour (Central Statistics Office 2006), and, assuming that most of these were working less than the mean figure of 28 hours a week reported for all sales workers in Table 1, this suggests weekly mean earnings for the workers in question of considerably less than the overall category mean of $€ 339.31$ given in Table 1 . This again points to the need to separate these two subgroups when devising an appropriate occupational taxonomy for the purposes of monitoring polarisation trends in the Irish labour force.

It should be noted that Table 1, being confined to employees, does not take into account employers and self-employed workers, who made up 13.2 per cent of all those in work (outside farming, fishing \& forestry) in the 2002 population census. Such workers (e.g. business proprietors, accountants, solicitors, craft workers), for the most part, have higher earnings than employees and are concentrated in highincome occupations. Inclusion of these in the earnings table, therefore, would further widen the degree of earnings dispersion between occupational groups. Overall, therefore, we conclude that in the early 2000 s there were substantial interoccupational variations in earnings in Ireland, and these corresponded closely with the income distribution configuration one would expect to arise from the social polarisation hypothesis.

According to this hypothesis, there should have been above-average growth in both high-income and low-income occupations, and below-average growth in intermediate occupations, over the last three decades. In order to facilitate analysis of recent occupational change in Ireland from this point of view, it is necessary to divide the labour force into a set of occupational groups which are internally homogenous in terms of skill levels and remuneration, while related to each other in a clear rank order. While the Standard Occupational Classification's nine broad occupational categories (as listed in Table 1) provide a good initial basis for such a taxonomy, the internal homogeneity criterion required some transfer of occupational subcategories between these broad categories and some merging of categories. The outcome of these adjustments has been the identification of the following six broad occupational groups which, it is argued, provide a reasonable basis for monitoring the extent to which social polarisation processes have been operational in Ireland in the period 1991-2002. ${ }^{4}$ 
1 Employers and managers: This occupational group is the equivalent of the managers and administrators category in Table 1, but has been renamed to acknowledge the inclusion in this category of owners of businesses as well as employed managerial workers. The main components of this group in 2002 were managers/proprietors of shops, and financial, marketing and production/works managers.

2 Professional: This group equates with the category of the same name in Table 1.

3 Associate professional/technical: This group consists of the category of the same name in Table 1, augmented by the transfer of certain occupational categories (including soldiers, police, chefs, hairdressers and auctioneers) from other occupational groups which otherwise are dominated by unskilled workers.

4 Clerical: This group equates with the clerical and secretarial category in Table 1.

5 Blue collar: This group combines the craft and related category from Table 1 with the truck, bus, train and mechanical plant drivers subcategories transferred from the plant and machine operatives category. This transfer is based on the fact that, in general, such drivers earn considerably more than the unskilled manufacturing workers who make up the bulk of the plant and machine operatives category: according to the Manpower Ireland Salary Guide for 2003 (Manpower Ireland 2003), average annual salaries for drivers of articulated trucks were one third higher than those for general operators/assemblers. Similarly, according to the Irish Independent (23 March, 2000), in 2000, drivers for Dublin Bus were earning $£ 5,000$ (i.e. approximately 28 per cent) more annually than the average industrial wage.

6 Unskilled: This group for the most part comprises occupations requiring minimal formal training and generally poor pay levels, and is divided into four subgroups - personal services (mainly carers and childminders, waitresses and bar staff, security guards and caretakers); sales (mainly sales assistants and checkout operators); unskilled industrial (mainly manufacturing operatives and assembly workers); and 'other' unskilled (mainly construction and general labourers, cleaners/domestics and counter hands and catering assistants).

Social polarisation theory would expect both the low-income (i.e. unskilled) and high-income (i.e. groups 1-3) occupational categories to have grown at above-average rates over the period 1991-2002, with the intermediate clerical and blue-collar categories experiencing relative decline. The growth of clerical work is expected to have been restrained partly by restrictions on the growth of public service employment (which is disproportionately clerical in nature) but mainly by the widespread adoption of data processing and transmission technology which 
has greatly reduced the need for a wide range of clerical tasks such as typing, filing, note-taking and telephone call making. In the blue-collar sector, a combination of deskilling and automation of industrial work is expected to have constrained (if not reversed) the growth of blue-collar industrial work although, in the Irish case, this will have been counterbalanced to a considerable extent by the expansion in demand for skilled construction workers resulting from the Irish economic boom of the 1990s and early 2000s.

Within the unskilled group, some exceptions to the overall expectation of rapid growth may be anticipated. Despite a rapid growth in the volume of retail sales (see below), expansion in the number of unskilled sales workers may have been significantly constrained by the impact of new technologies in such areas as inventory control, bar coding, and automated checking-out (Webster 1999). As regards unskilled industrial workers, while Atkinson (1985) had expected the numbers of these to grow at the expense of semi-skilled blue-collar workers as a result of the restructuring of industrial work, this may have been offset both by the automation of the routine production work which unskilled assembly workers perform, and by the offshoring of such work to low-cost locations elsewhere in the world.

\section{Occupational change in Ireland, 1991-2002: preliminary analysis}

This section presents a preliminary analysis of the pattern of occupational change in Ireland between 1991-2002, employing the broad occupational groups identified in the previous section. Table 2 shows the overall rate of change in these groups over the period. While all of the groups shown experienced growth over the period, there were sharp inter-group differences, with the employers/managers, professional and associate professional/technical groups all experiencing growth rates well above the average for all occupations, whereas growth in the blue collar, unskilled and clerical groups was well below average. These trends are all very much in line with what would be expected from social polarisation theory, with the exception of the relatively slow growth in the number of workers in unskilled occupations; indeed, the overall pattern of change apparent in Table 2 provides clear support for the alternative professionalisation hypothesis, with low-income occupations in decline and high-income occupations expanding strongly.

In order to investigate this unexpected outcome further, the unskilled occupational group was subdivided into its constituent subgroups and the rates of change for these were examined over the two intercensal periods 1991-6 and 1996-2002 (Table 3). This shows, first of all, that the combined unskilled group displayed above-average growth between 1991-6 but dropped to almost zero growth in the second period when the overall rate of growth for all occupations accelerated substantially. Secondly, while the rate of growth for the sales subgroup did show an increase in the second period, in both periods it was well below the overall average, in line with hypothetical expectations. Thirdly, the other three 
Table 2: Employment change by broad occupational group 1991-2002

\begin{tabular}{lcrrrr}
\hline & $\begin{array}{c}\text { Workers } \\
1991\end{array}$ & $\begin{array}{c}\text { \%all } \\
\text { workers } \\
1991\end{array}$ & $\begin{array}{c}\text { \% change } \\
\text { 1991-2002 }\end{array}$ & $\begin{array}{c}\text { Empl. } \\
2002\end{array}$ & $\begin{array}{c}\text { \% all } \\
\text { workers } \\
\end{array}$ \\
& $1,183,306$ & 100.0 & 42.3 & $1,683,507$ & 100.0 \\
\hline All occupations $^{1}$ & 128,632 & 10.9 & 92.1 & 247,123 & 14.7 \\
Employers/managers & 108,634 & 9.2 & 57.4 & 171,024 & 10.2 \\
Professional & 161,236 & 13.6 & 56.4 & 252,213 & 15.0 \\
Associate professional/ technical & 173,689 & 14.7 & 17.3 & 203,671 & 12.1 \\
Clerical & 242,279 & 20.5 & 11.0 & 268,980 & 16.0 \\
Blue collar & 342,147 & 28.9 & 20.6 & 412,622 & 24.3 \\
Unskilled & 26,689 & 2.3 & 379.1 & 127,874 & 7.6 \\
Unstated & & & & & \\
\hline
\end{tabular}

${ }^{1}$ Excluding Agriculture, Forestry \& Fishing

subgroups all show a very substantial fall in growth between the two periods (turning into a significant decline in the case of the 'other unskilled' subgroup). The marked slowdown, in the 1996-2002 period, of growth in the numbers of workers in unskilled industrial occupations following strong growth in the previous intercensal period is consistent with the findings of the CSO's Census of Industrial Production which shows the number of manufacturing operatives to have grown by 27 per cent between 1991-96 but to have stagnated between 1996-2002.

Table 3: Employment change in unskilled occupations by subgroups

\begin{tabular}{lcc}
\hline & \% change & \% change \\
& 1991-1996 & 1996-2002 \\
\hline All occupations & 15.4 & 23.3 \\
All unskilled & 18.9 & 0.7 \\
Personal services & 47.5 & 15.0 \\
Sales & 5.1 & 8.9 \\
Industrial & 22.3 & 4.4 \\
Other unskilled & 8.0 & -12.8 \\
\hline
\end{tabular}

The stagnation apparent in unskilled industrial and sales occupations during 1996-2002 is, therefore, readily amenable to explanation. This is not the case, however, with the experiences of the other two unskilled subgroups depicted in Table 3. The sharp drop in the rate of growth of unskilled personal service occupations (made up mainly of childminders and carers, waitresses and bar staff, 
security guards and caretakers) at a time of unprecedented economic growth runs directly counter to everyday experience and analytical expectation. The apparent sharp fall in the number of workers in the 'other unskilled' subgroup is even more anomalous. By far the biggest component of this subgroup are building and construction labourers whose numbers are reported in the census to have fallen by 4.8 per cent between 1996-2002. This is directly at odds with the fact that the number of workers in blue-collar construction occupations grew by 31.4 per cent in the same period, and with the general boom in the construction industry in the period in question.

In looking for an explanation for the apparently anomalous stagnation in the number of unskilled workers between 1996-2002, an obvious source is the rapid growth in the number of workers who did not state their occupation in the same period. In 1991 the number of workers with unstated occupations represented just 2.4 per cent of all workers (excluding farming, fishing and forestry), a figure which rose only marginally, to 2.6 per cent, in 1996. However, between 1996-2002, the number of workers with unstated occupations grew hugely (by 255.6 per cent) with the result that its share of the total jumped to 7.6 per cent. The fact that this upsurge coincided with an unexpected stagnation in the reported number of workers in unskilled occupations suggests a causal connection between the two developments.

\section{Explaining the high level of workers with unstated occupations in 2002}

What explains the surge, between 1996-2002, in the number of workers with unstated occupations? In response to a query on this matter, the CSO (personal communication, 21 March, 2007) suggested that it may have been due to misinterpretation by some respondents of a filter question introduced for the first time in the 2002 census form, and which may have caused them to skip the questions relating to occupation and industrial classification of employer. If this explanation is correct, it would suggest that the incidence of unstated occupations was concentrated among people of lower education levels and/or whose ability to understand English was weak. The latter possibility points to the rapid recent growth in the number of non-English-speaking foreign nationals in the Irish labour force as a potential explanation for the sharp rise between 1996-2002 in the number of census respondents who did not state their occupation. The number of persons enumerated in the census as being born outside Ireland, Britain and the USA rose by 12,830 between 1991-6 and by 102,530 between 1996-2002. ${ }^{5}$ These figures are quite similar, in order of magnitude, to the growth in the number of persons with unstated occupations over these two periods $(7,267$ and 91,918 , respectively). It is well known that such immigrants - even where they have good educational qualifications - are strongly concentrated in unskilled employment (Hughes and Quinn 2004, Mac Éinrí and Walley 2003, Minns 2005). However, analysis of the five per cent Sample of Anonymised Records (SAR) issued by the $\mathrm{CSO}^{6}$ as an aid to researchers does not support the proposition that those who did 
not state their occupation in the 2002 census were mainly foreign nationals: in fact, only 17 per cent of them stated that they were born outside Ireland, and one third of these were born in Britain or the USA and were presumably Englishspeaking.

Three other reasons for non-completion of the census question may be suggested. The first of these is the increasing incidence in Ireland of labour market fragmentation (e.g. multiple jobbing, frequent movement between jobs, growing prevalence of part-time, temporary and casualised work) which, as O'Shea (2002) observes, has made it increasingly difficult to classify many people's occupations. Such fragmentation is likely to be particularly concentrated in areas of unskilled work. Many census respondents, therefore, may not have stated their occupations because they could not identify themselves with a particular occupation. Secondly, census respondents may have been wary of completing the census question where they were working illegally. It is noteworthy in this respect, that the kinds of occupations which dominate the anomalous subgroups in Table 3 (cleaners, carers and childminders, hotel, restaurant and bar workers, construction labourers and general labourers) are classic 'black economy' occupations. This again points to the concentration of those who did not state their occupation in unskilled occupations. Thirdly, many respondents may not have stated their occupation simply because they did not have one: a notable feature of those who did not state their occupation in the 2002 census (as indicated in the 5 per cent SAR) is that a very large proportion of them were not working at all - no less than 38.2 per cent (compared with just 5.7 per cent for those with stated occupations). Of this unemployed group (excluding those for whom the information was not available), 62.8 per cent had ceased education at age 16 or below, pointing to a group characterised by very low skill levels. It is likely that what we have here is a residual core group of long-term unemployed who, as O'Shea (2002) suggests, may be difficult to classify in occupational terms because of the long time spent out of work.

Further evidence of the likely occupational configuration of those who did not state their occupation in the 2002 census is provided by a comparison between the 2002 census returns and the findings of the Quarterly National Household Survey (QNHS) for the second quarter of 2002 (the period during which the census was conducted). The QNHS is a very substantial survey, involving 39,000 households, and therefore can be expected to possess a high degree of accuracy. Furthermore, it has no reported cases of unstated occupations, and therefore can be regarded as providing a more thorough indicator of the occupational distribution of the labour force. However, in order to compare the QNHS occupational distribution with that of the 2002 census, it was necessary to recast the latter into the same broad occupational categories as those used by the QNHS (i.e. those shown in Table 1).

The occupational distributions for the QNHS and the census (as recast) are shown in Table 4. This shows that seven of the nine occupational categories (excluding the unstated category) constitute smaller proportions of the census returns than of the corresponding QNHS returns. It is assumed that the 'true' 
occupations of those whose occupations are unstated properly belong to these seven categories in proportion to each category's degree of shortfall from the share of the corresponding QNHS categories. Thus, the four mainly unskilled categories account for 37.2 per cent of the QNHS returns but only 32 per cent of the census returns i.e. there is a shortfall of 5.2 percentage points. We assume, therefore, that these four categories represent 5.2 of the 7.2 percentage points (i.e. 72 per cent) of the census returns accounted for by unstated occupations. This supports the contention that most of those who did not state their occupations in the census returns were, in fact, from an unskilled background.

Table 4: Occupational distribution: 2002 census and Quarterly National Household Survey (QNHS) for March-May 2002 compared

\begin{tabular}{lcr}
\hline Occupational categories $^{l}$ & 2002 census & QNHS \\
\hline Managers \& administrators & 18.3 & 17.8 \\
Professional & 9.6 & 10.7 \\
Associate professional/technical & 9.0 & 8.8 \\
Clerical \& secretarial & 11.4 & 12.7 \\
Craft \& related & 12.5 & 12.8 \\
Personal \& protective services & 8.6 & 9.6 \\
Sales & 6.3 & 8.2 \\
Plant \& machine operatives & 9.3 & 10.5 \\
Other & 7.8 & 8.9 \\
Unstated & 7.2 & - \\
\hline
\end{tabular}

${ }^{1}$ Includes workers engaged in farming, forestry and fishing

Accordingly, the census data were then recast so that each occupational category had the same proportionate share as for the corresponding QNHS categories. This has the effect of redistributing those with unstated occupations among the remaining occupational categories in proportion to their degree of shortfall in relation to the QNHS categories. It was then necessary to redistribute (or exclude, in the case of workers in farming, forestry and fishing) certain occupational subcategories in order to reconstitute the six broad occupational groups being used for the analysis of occupational change (as listed in Table 2). ${ }^{7}$ Table 5 shows, for each of the reconstituted broad occupational groups, the changes wrought by the reallocation of unstated occupations on the original occupational distribution in the 2002 census. All of the occupational groups increased their share of the total population of workers with the exception of the employers \& managers and associated professional \& technical groups, both of whose shares fell slightly. However, the increase in the share of the unskilled group was much greater than that of any other group, even allowing for this group's large initial 
share. Thus, with 24.5 per cent of all workers prior to redistribution, this group (as indicated above) accounted for 72 per cent of those whose occupations had originally been unstated.

Table 5: Revision of 2002 census occupational distribution based on Quarterly National Household Survey

\begin{tabular}{lccccc}
\hline & $\begin{array}{c}\text { Number of } \\
\text { workers, } \\
\text { original } \\
\text { census }\end{array}$ & $\begin{array}{c}\% \text { of } \\
\text { total }\end{array}$ & $\begin{array}{c}\text { Adjustment } \\
\text { based on } \\
\text { QNHS }\end{array}$ & $\begin{array}{c}\text { Adjusted } \\
\text { number } \\
\text { of } \\
\text { workers }\end{array}$ & $\begin{array}{c}\% \text { of } \\
\text { total } \\
\text { (adjusted) }\end{array}$ \\
\hline All occupations ${ }^{1}$ & $1,683.5$ & 100.0 & 0 & $1,683.6$ & 100.0 \\
Employers/managers & 247.1 & 14.7 & -6.5 & 240.6 & 14.3 \\
Professional & 171.0 & 10.2 & +20.1 & 191.1 & 11.4 \\
Associate professional/ technical & 252.2 & 15.0 & -4.8 & 247.4 & 14.7 \\
Clerical & 203.7 & 12.1 & +22.3 & 226.0 & 13.4 \\
Blue collar & 268.9 & 16.0 & +7.5 & 276.4 & 16.4 \\
Unskilled & 412.7 & 24.5 & +89.4 & 502.1 & 29.8 \\
Unstated & 127.9 & 7.6 & -127.9 & 0 & 0 \\
\hline
\end{tabular}

${ }^{1}$ Excludes workers engaged in farming, forestry and fishing

In the interests of comparability and consistency, it was desirable to make similar revisions to the occupational distributions reported in the 1991 and 1996 censuses. However, there was no quarterly QNHS (which was introduced in 1997) corresponding to the dates of these censuses, while the annual Labour Force Survey which preceded the QNHS used a different occupational classification from that used in the QNHS. The unstated occupations for the earlier censuses were therefore divided among the other occupational categories in the same proportions as was used for the 2002 census. Given the small proportions of unstated occupations for the earlier censuses -2.1 per cent for 1991 and 2.4 per cent for 1996 compared with 7.2 per cent for 2002 - any errors arising from this procedure are likely to be small.

\section{Occupational change in Ireland, 1991-2002: revised analysis}

Table 6, which shows the pattern of change among occupational groups (and subgroups, where relevant) between 1991-2002 following redistribution of those with unstated occupations, presents quite a different picture of occupational change compared with Tables $2 \& 3$. Predictably, the redistribution of workers with unstated occupations has had a particularly marked impact on the unskilled 
group, raising its rate of growth between 1996-2002 from 0.7 per cent, as initially calculated, to 16.8 per cent following redistribution, and from 20.6 per cent to 38.6 per cent for 1991-2002. This still leaves the rate of growth for this group below that for all occupations but, as Table 6 shows, disaggregation of this group into its constituent subgroups reveals major differences in behaviour over time between these subgroups - behaviour which also differs very profoundly from that originally portrayed in Table 3 . Thus, whereas personal services were initially portrayed as displaying below-average growth between 1996-2002, following revision this growth was well above average and was more than double the overall average for 1991-2002. Revision produced even more far-reaching change with respect to sales. While the rate of growth for 1991-1996 in Table 6 (7.2 per cent) is slightly above that originally calculated ( 5.1 per cent), it nonetheless remains quite modest and well below the overall average, as expected. However, this was followed by a marked acceleration for the second intercensal period, during which period the growth rate was well above average. As a result, the overall growth rate for 1991-2002 (47.8 per cent) was significantly above average.

Table 6: Rates of change in revised occupational groups and subgroups

\begin{tabular}{lrcccc}
\hline & $\begin{array}{c}\text { \% all } \\
\text { workers }\end{array}$ & $\begin{array}{c}\text { \% change } \\
\text { 1991-1996 }\end{array}$ & $\begin{array}{c}\text { \% change } \\
\text { 1996-2002 }\end{array}$ & $\begin{array}{c}\text { \% change } \\
\text { 1991-2002 }\end{array}$ & $\begin{array}{c}\text { \% all } \\
\text { workers } \\
2002\end{array}$ \\
\hline All occupations & 1901 & & & & 100.0 \\
Employers/managers & 10.7 & 24.6 & 51.8 & 89.2 & 14.3 \\
Professional & 9.6 & 20.2 & 40.6 & 69.0 & 11.4 \\
Associate prof/technical & 13.5 & 23.8 & 24.8 & 54.5 & 14.7 \\
Clerical & 15.1 & 7.9 & 17.4 & 26.5 & 13.4 \\
\hline & & & & & \\
Blue collar & 20.6 & 2.8 & 10.2 & 13.3 & 16.4 \\
$\quad$ of which: & & & & & \\
$\quad$ Industrial & 11.0 & -3.0 & -7.2 & -10.0 & 6.9 \\
$\quad$ Construction & 6.1 & 14.3 & 34.0 & 53.1 & 6.6 \\
$\quad$ Drivers & 3.6 & 0.7 & 16.0 & 16.8 & 2.9 \\
\hline Unskilled & & & & & \\
$\quad$ of which: & 30.6 & 18.7 & 16.8 & 38.6 & 29.8 \\
$\quad$ Personal services & & & & & \\
$\quad$ Sales & 5.3 & 46.0 & 28.4 & 87.4 & 7.0 \\
$\quad$ Industrial & 6.4 & 7.2 & 37.9 & 47.8 & 6.6 \\
$\quad$ Other & 8.6 & 22.5 & 16.6 & 42.9 & 8.6 \\
\hline & 10.3 & 8.6 & -3.8 & 4.4 & 7.6 \\
\hline
\end{tabular}


This upsurge in the rate of growth in the number of unskilled sales workers (primarily sales assistants, checkout operators and petrol pump attendants) can be attributed to the fact that this subgroup attracted a disproportionate share of the redistributed workers with unstated occupations, in line with the findings of the QNHS. Alternative information sources on trends in retail employment confirm that a major acceleration in retail sales employment occurred in the period after 1996. According to data from the QNHS quoted in KPMG Management Consultants et al. (1999), retail employment grew by only 5.3 per cent between 1988-96, while data from the CSO Annual Service Enquiries, covering a similar range of retail activities, indicate that retail employment grew by 41.8 per cent between 1997-2002 (Central Statistics Office 2002, 2004). These growth rates are very similar in order of magnitude to the growth rates for unskilled sales between 1991-6 and 1996-2002 reported in Table 6, providing strong support for the procedures for redistributing unstated occupations used in compiling the latter table.

The explanation for the acceleration in the growth of employment in unskilled sales after 1996 presumably lies in the consumer boom which enveloped the maturing 'Celtic Tiger' economy in the late 1990s and early 2000s. In volume terms, retail sales in Ireland grew by 46.6 per cent between 1996-2002 compared with a much more modest 19.5 per cent between 1991-6 (Central Statistics Office 2002, Department of Finance 1997). A key feature of employment growth in the retail sector during this period was the extent to which it involved part-time employment. According to KPMG Management Consultants et al. (1999), in 1988 27.4 per cent of retail employees in Ireland were part-time workers; by 2002 this had risen to 43.3 per cent (Central Statistics Office 2004). Given the postulated link between part-time employment and unstated occupations (especially in the retailing sector where many workers only work a few hours per week), the fact that nearly one half of unskilled sales workers were part-time provides a ready explanation for the apparently high number of such workers who did not state their occupation in the 2002 census.

Table 6 shows the unskilled industrial subgroup displaying much stronger growth during 1996-2002 than was evident in Table 3, although below the overall rate of employment growth and also below the rate of growth for the same subgroup in the earlier intercensal period. There is a clear anomaly between the 16.6 per cent growth in the number of unskilled industrial workers reported for 1996-2002 in Table 6 and the zero growth for manufacturing operatives reported in the CSO's Census of Industrial Production for the same period. A possible explanatory factor here might be the significant fall in manufacturing employment which occurred after 2000 (according to the Census of Industrial Production, the number of operatives in manufacturing industry fell by seven per cent between 2000-2 having grown by 27 per cent over the previous nine years) in that disemployed operatives may not have stated their former occupation in the census but may have done so when being interviewed for the QNHS. 
In the case of the 'other unskilled' component of Table 6, the strong decline registered after 1996 in Table 3 has been replaced by modest growth. One presumes that this reversal reflects, to a considerable extent, large-scale non-declaration of their occupations by construction labourers and cleaners/domestics who constitute a substantial proportion of workers in this occupational subgroup.

Elsewhere in Table 6, the redistribution of unstated occupations has had the effect of reducing somewhat the rate of growth of the employers/managers group while, interestingly, increasing that of the professional group. This suggests, somewhat surprisingly, that a disproportionately high number of those who did not state their occupation were professional workers. It may be that some of these were semi-retired people still practising their profession in the informal economy but not prepared to declare it on the census form: to quote O'Shea (2002: 255): 'Older workers may ... retain an attachment to work even when they retire early from their lifetime occupation, working on an informal basis outside of mainstream employment'. It is also possible that some of these were immigrant workers, whose educational and occupational profile in general is significantly higher than that of the indigenous population: according to the 5 per cent SAR, of those immigrants from 'Other EU' (i.e. outside the UK) and 'other countries' (outside the USA and EU) - the principal sources of the recent immigration surge - who did not state their occupation in the 2002 census, 36.7 per cent had third level education compared with just 15.9 per cent of the corresponding indigenous group.

Redistribution has almost doubled the growth rate of the clerical group, to 26.5 per cent, over the period 1991-2002. This suggests that many clerical workers are operating in the informal economy. At the same time, the revised growth rate remains well below the overall average, in line with social polarisation theory. Redistribution has had only a minor impact on the blue-collar group. However, while the growth of this group as a whole remains well below the overall average, the experiences of the subgroups making up this group were quite variable, with industrial blue collar workers experiencing significant decline (as expected according to polarisation theory) and construction workers experiencing aboveaverage growth (readily explicable in the context of Ireland's construction boom).

Overall, then, Table 6 portrays many features which comply with key tenets of social polarisation theory. Strong growth is apparent in higher-level employer, managerial, professional and technical occupations and also in certain unskilled occupations (personal service and sales), while there has been relative contraction among clerical workers and industrial blue-collar occupations. However, whereas those unskilled subgroups which did experience above-average growth (personal services and sales) only increased their share of total employment by 1.9 percentage points, the managerial, professional \& technical groups saw their combined share grow by 6.6 percentage points. Overall, the proportion of the labour force accounted for by the latter groups rose from 33.8 to 40.4 per cent, while the proportion taken by the combined unskilled group actually fell, from 30.6 to 29.8 per cent. However, the main loss of employment share was experienced by the 
intermediate clerical and blue-collar groups whose combined share of the labour force fell from 35.7 to 29.8 per cent - clear evidence of the 'disappearing middle' concept associated with the social polarisation hypothesis (Belchamber 1996). Thus, on balance, there was a significant overall upgrading of the occupational profile of the Irish labour force over the period, as postulated by the professionalisation hypothesis.

The experience of public service employment between 1991-2002 provides additional evidence of the operation of polarisation processes in the Irish labour force in this period. Public service workers have, along with blue-collar manual workers, been identified in the social polarisation literature as a bastion of the middle-income groups which dominated the employment structure of the Fordist welfare state but whose position was subsequently eroded as part of the postFordist restructuring process (Gallie 1996, Marshall, Hopkins and Richardson 1997). Public service workers have not been considered hitherto in this paper because they are distributed among the occupational groups already analysed in Tables 1-6. However, it has been possible to identify a number of occupational groups in the census data whose members are entirely or predominantly public service workers. These include clerical and administrative workers in the central civil service and local government, teachers, nurses and nurses' aids, social workers, the fire and prison services, police and armed forces and a range of minor public service occupations. This grouping excludes workers in state companies and semi-state agencies and also many professional/technical public service workers who could not be identified separately. The undercounting of public service workers due to these exclusions is counterbalanced, to an extent, by the inclusion of some private sector workers in the nurses and teachers categories. The overall growth rate of public service occupations (as defined here), at 32.7 per cent between 1991-2002, ${ }^{8}$ was below the overall rate of growth in all occupations (42 per cent) and was considerably below the high-growth groups identified in Table 6. This grouping, therefore, has also experienced significant contraction in its employment position relative to the latter groups, in line with the postulates of the social polarisation thesis.

\section{Trends in female employment}

The role of trends in female employment has been a topic of particular interest in the literature on social polarisation. While this literature has tended to emphasise the role of women workers in the growth of low-grade employment only (Badcock 1997, Gregson and Lowe 1994, Yates 1996), a notable feature in the changing occupational configuration of the Irish workforce has been the leading role played by such workers at both ends of the occupational spectrum (Table 7). The period under review saw a significant growth in the female share of the Irish labour force, with the number of female workers growing at more than twice the rate of that for males. While women led the way in the growth of higher-grade occupations, there 
was also robust male growth in these sectors. By contrast, strong female growth in unskilled occupations was accompanied by weak or even negative growth among males in these occupations. Thus, the process of feminisation of the labour force has been proceeding much more vigorously at this end of the occupational spectrum. However, the exception to this was the spectacular growth in the number of female employers and managers which, at 154.7 per cent between 1991-2002, was two-and-a-half times the rate of growth both for all female workers and for male employers and managers in this period.

Table 7: Trends in female employment

\begin{tabular}{lccccc}
\hline & $\begin{array}{c}\text { Female } \\
\%\end{array}$ & $\begin{array}{c}\text { \% change } \\
\text { all }\end{array}$ & $\begin{array}{c}\text { \% change } \\
\text { females }\end{array}$ & $\begin{array}{c}\text { \% change } \\
\text { males }\end{array}$ & $\begin{array}{c}\text { Female } \\
\%\end{array}$ \\
& 1991 & $1991-2002$ & $1991-2002$ & $1991-2002$ & 2002 \\
\hline All occupations & 37.6 & 42.1 & 64.6 & 28.5 & 43.5 \\
Employers/managers & 28.4 & 89.2 & 154.7 & 61.0 & 38.6 \\
Professional & 47.3 & 69.0 & 75.3 & 64.7 & 53.0 \\
Associate prof/technical & 44.3 & 54.5 & 73.8 & 39.2 & 49.8 \\
Clerical & 68.7 & 26.5 & 41.9 & -5.0 & 76.6 \\
\hline Blue collar & 10.4 & 13.3 & -46.1 & 20.3 & 5.0 \\
$\quad$ of which: & & & & & \\
$\quad$ Industrial & 18.6 & -10.0 & -53.5 & 0.0 & 9.6 \\
$\quad$ Construction & 1.0 & 53.1 & 100.0 & 52.7 & 1.3 \\
$\quad$ Drivers & 1.4 & 16.8 & 83.3 & 15.8 & 2.2 \\
\hline Unskilled & 38.1 & 38.6 & 73.1 & 17.4 & 47.6 \\
$\quad$ of which: & & & & & \\
$\quad \begin{array}{l}\text { Personal services } \\
\text { Sales }\end{array}$ & 51.1 & 87.4 & 142.2 & 30.4 & 66.0 \\
$\quad$ Industrial & 61.5 & 47.8 & 75.6 & 3.4 & 73.0 \\
$\quad$ Other & 27.7 & 42.9 & 55.3 & 38.2 & 30.1 \\
\hline & 26.4 & 4.4 & 29.7 & -4.7 & 32.8 \\
\hline
\end{tabular}

Even in the low-growth clerical occupational group, already dominated by women workers, the process of feminisation is evident, with reasonably strong growth in the number of females being accompanied by contraction in the number of males. The only occupational group which experienced a decline in the female share was the blue-collar sector in which female participation was already low. Here, the sharp fall in the number of female industrial blue-collar workers is almost entirely attributable to the collapse of the Irish clothing and textile industry in the 1990s. In the other two blue-collar subgroups the female share actually rose, but from a miniscule initial base in both cases. Interestingly, while female 
employment in blue-collar industrial work has been falling sharply, there has been quite strong growth in the number of unskilled female industrial workers. The main sectors in which such workers are found are electrical/electronic and engineering assembly. However, these sectors have been experiencing substantial contraction in the early 2000s due mainly to relocation to other, more low-cost locations elsewhere, and one would expect the 2006 census to show a significant fall in the number of workers in these sectors.

\section{Conclusion}

Overall, this paper has found that the patterns regarding occupational change in Ireland for the period 1991-1996 identified by Breathnach (2002b) generally held true for the longer 1991-2002 period, coinciding with the high point of the 'Celtic Tiger' phenomenon. While strong growth in the employers/managers and professional/technical occupational groups has resulted in a general upgrading in the occupational structure, there has also been strong simultaneous growth in certain unskilled and poorly-paid occupations, especially in personal services and retail sales. However, the growth in unskilled work has been tempered by the application of automated technology in both retailing and manufacturing (accompanied, in the latter case, by an amount of relocation to cheap labour sites abroad). Automation is also having an impact on more routine, and mainly female, clerical work. Meanwhile, the middle-income occupational groups which occupied key positions in the post-war Fordist social structure have been experiencing either absolute (in the case of blue-collar industrial work) or relative (in the case of public service employment) decline.

Female workers have been to the forefront in driving this process of occupational change. Rising levels of education, growing demand for highly educated professional personnel and widening business opportunities lie behind a rapid growth in the number and proportion of women taking professional and technical courses in higher education institutions and in starting their own businesses. As a result, the rate of growth in the number of female professional/technical workers and (especially) employers/managers greatly exceeded that for males in the 1990s and early 2000s. At the same time, rapidly rising demand for workers in key unskilled occupational categories, and especially in personal services, has seen large numbers of Irish women from lower social backgrounds as well as female migrant workers from abroad increasingly being drawn into the Irish paid labour force.

We conclude, therefore, that the profound occupational restructuring which has been going on in Ireland at least since the beginning of the 1990s has involved both an increasing professionalisation and polarisation of the Irish workforce, with the growth of female employment playing a key role in driving both these processes. 


\section{Notes}

1 See Breathnach (2002b) for a full discussion of the processes and mechanisms associated with the social polarisation hypothesis.

2 The census originally intended for 2001 was postponed due to the imposition of movement restrictions designed to forestall a threatened outbreak of foot-and-mouth disease.

3 In all the relevant tables in the National Employment Survey (NES), the figures for weekly earnings are invariably higher than the product of mean hourly earnings and mean weekly hours worked. No explanation is given for this, but it may be related to adjustments made to the NES sample to bring it into correspondence with the population of employees recorded in the Quarterly National Household Survey, referred to in the Background Notes to the NES (Central Statistics Office 2006: 38).

4 A full listing of the occupational categories allotted to each broad occupational group in the recast occupational taxonomy is available from the author on request. Those working in the farming, forestry and fishing sectors have been excluded from the analysis, as these sectors are subject to special regulatory circumstances and secular trends which are largely uninfluenced by social polarisation processes.

5 These figures include persons not normally resident in Ireland, although some of these will have been in temporary or casual employment.

6 Thanks are expressed to the referee who suggested the use of this valuable data source. 7 For reasons of space, the methodology employed in redistributing unstated occupations has not been detailed here, but is available on request from the author.

8 No allowance has been made for unstated occupations here, it being assumed that nonreporting of occupations by public service employees was minimal.

\section{References}

Atkinson, J. 1985 'The changing corporation', pp. 17-34 in D. Clutterbuck (ed.), New Patterns of Work. Aldershot: Gower.

Badcock, B. 1997 'Restructuring and social polarisation in cities', Progress in Human Geography 21 (2): 251-62.

Belchamber, G. 1996 'Disappearing middle or vanishing bottom? A comment on Gregory', Economic Record 72, 218: 287-93.

Breathnach, P. 2002a 'Information technology, gender segmentation and the relocation of back office employment: the growth of the teleservices sector in Ireland', Information, Communication and Society 5 (3): 320-35.

Breathnach, P. 2002b 'Social polarisation in the post-fordist informational economy: Ireland in international context', Irish Journal of Sociology 11 (1): 3-22.

Castells, M. 1996 The Rise of the Network Society. Oxford: Blackwell.

Central Statistics Office 2002 Statistical Yearbook of Ireland 2002. Dublin: Stationery Office.

Central Statistics Office 2003 Census 2002, Volume 6 (Occupations). Dublin: Stationery Office.

Central Statistics Office 2004 Annual Services Enquiry 2002. Dublin: Stationery Office.

Central Statistics Office 2006 National Employment Survey 2003. Dublin: Stationery Office.

Central Statistics Office 2007 Public Sector Employment And Earnings, September 2006, Dublin. 
Department of Finance 1997 Economic Review And Outlook 1997. Dublin: The Stationery Office.

Flynn, Gerald 2000 'Bus strike row escalates', Irish Independent, 23 March, 2000.

Gallie, D. 1996 'Skill, gender and the quality of employment', pp. 133-59 in R. Crompton, D. Gallie and K. Purcell (eds), Changing forms of employment: organisations, skills and gender. London: Routledge.

Graham, S. and S. Marvin 1996 Telecommunications and the City: Electronic Spaces, Urban Places. London: Routledge.

Gregson, N. and M. Lowe 1994 Servicing the Middle Classes: Class, Gender and Waged Domestic Labour in Contemporary Britain. London: Routledge.

Hamnett, C. 1994 'Social Polarisation in global cities: theory and evidence', Urban Studies 31 (3): 401-24.

Harrison, B. 1997 Lean and Mean: Why Large Corporations Will Continue to Dominate the Global Economy. New York: Guilford Press.

Hughes, G. and E. Quinn 2004 The Impact of Immigration on Europe's societies: Ireland. Dublin: European Migration Network/Economic and Social Research Institute.

KPMG Management Consultants, Fitzpatrick Associates Economic Consultants and UCD Centre for Retail Studies 1999 The Dynamics of the Retail Sector in Ireland. Dublin: Forfás.

Mac Éinrí, P. and P. Walley 2003 Labour Migration into Ireland. Dublin: Immigration Council of Ireland.

Manpower Ireland 2003 'Salary Guide 2003', http://www.manpower.ie/jobseekers/ SalaryGuide160103c.pdf, access date 25 March, 2007.

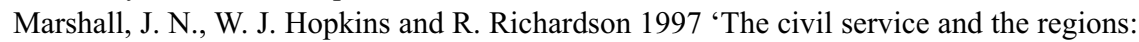
geographical perspectives on civil service restructuring', Regional Studies 31 (6): 607-13.

Minns, C. 2005 'Immigration policy and the skills of Irish immigrants: evidence and implications', IIIS, Trinity College Dublin, Discussion Paper, No. 68.

O'Connell, P. J. 2000 'The dynamics of the Irish labour market in comparative perspective', pp. 58-89 in B. Nolan, P. J. O'Connell and C. Whelan (eds), Bust to Boom? The Irish Experience of Growth and Inequality. Dublin: Institute of Public Administration.

O'Hearn, D. 2000 'Globalisation, "new tigers" and the end of the developmental state? The case of the Celtic Tiger', Politics and Society 28 (1): 67-92.

O'Shea, E. 2002 'Measuring trends in male mortality by socio-economic group in Ireland: a note on the quality of the data', Economic and Social Review 33 (2): 247-57.

Webster, J. 1999 'Technological work and women's prospects in the knowledge economy: an agenda for research', Information, Communication and Society 2 (2): 201-21.

Yates, M. 1996 'Nice work if you can get it', Monthly Review 48 (7): 51-6. 